\title{
ARID ZONE PROBLEMS
}

\begin{abstract}
A GENERAL symposium on the "Problems of the Arid Zones" was held at Unesco Headquarters in Paris during May 11-18. It was attended by more than two hundred delegates, representing twenty scientific disciplines, from thirty-four countries, the latter including all the major arid areas of the world; the U.S.S.R., the United States, France and the United Kingdom were all well represented.

The symposium was opened by $\mathrm{Mr}$. Vittorino Veronese, director-general of Unesco, who warmly welcomed the distinguished delegates from so many countries. He directed attention to the importance of the arid zones, which cover one-third of the Earth's surface, in relation to the need for increasing the food resources of the rapidly increasing world population, which has already reached the 2,000 million mark, and is expected to double itself within the next fifty years. The universal character of the results of research in the arid lands and the importance of employing them to the common good make this research a suitable field for international action, particularly through Unesco, which is charged by its constitution to promote scientific research with the view of improving the living conditions of mankind.

The director-general introduced the president of the symposium, M. P. Piganiol, delegate-general for scientific research of the Government of France, whose responsibilities cover the organization of scientific research in that country; he addressed the delegates on the main problems to be faced by the symposium, the principal object of which was to evaluate the results already achieved and to make recommendations regarding the future course of arid zone research.
\end{abstract}

The general arrangements for the symposium, which followed the recommendations of the Unesco Advisory Committee for Arid Zone Research at its meeting in Madrid in September 1959, were carried out with great care and efficiency by the Arid Zone Unit of the Unesco staff. Review papers covering the principal scientific disciplines were requested from acknowledged leaders in their particular fields, and the discussions that followed added considerably to the value of the papers. The Proceedings of the symposium, which should be of considerable scientific interest and value, will be published in English and in French by Unesco in its Arid Zone Research Series.

In 1951 Unesco was given the task of promoting research in the arid zones, which for this purpose are taken as including also the semi-arid areas; by an extension of stock raising and the building of great new irrigation schemes in suitable areas, these zones are capable of augmenting considerably world food supplies. This basic research led to such interesting and useful results that in 1957 the activities were raised to the rank of a major project, whereby increased funds were made available for it with special reference to the arid belt extending across northern Africa from Morocco to Egypt and thence through the Middle East to Pakistan and India. Following eight years of activity on the many facets of arid zone research, including three years devoted to the rnajor project, the general symposium has been hold with the object of reviewing the results of this research and to suggest new directions of useful activity.

Also, since the major project is due to be terminated at the end of 1962, this review had to be made now in order to provide in good time for the continuation of arid zone research after 1962. The General Conference of Unesco in 1958, in approving the holding of the general symposium, had directed the directorgeneral to submit to it in November, 1960, a report on the past effectiveness, and recommendations for the future course, of the major project, on the basis of the study and recommendations of the symposium.

In order to achieve this purpose, the symposium was divided into four parts.

\section{(I) Critical Appraisal of the State and Perspectives of Knowledge in the Various Scientific Disciplines Involved}

For this part of the symposium, review papers were presented in the following fields of science, most of which have formed the subjects of symposia or research reviews organized under the Unesco Arid Zone Programme :

(i) Surface hydrology (including sedimentation) Dr. W. B. Langbein, U.S. Geological Survey, Washington.

(ii) Geology, geomorphology and ground-water hydrology-Dr. F. Dixey, former director of Overseas Geological Surveys, London.

(iii) Climatology (including hydro-meteorology)Dr. C. C. Wallen, Swedish Hydrological and Meteorological Service, Stockholm.

(iv) Microclimatology (physical and biological)Prof. W. R. Van Wyk and Prof. J. do Wilde, Agricultural University, Wageningen.

(v) Soil science (including soil conservation)-Dr. Georges Aubert, Chef du Service des Sols del'Office de la Recherche Scientifique et Technique Outre-Mer, Paris.

(vi) Salinity problems of plants and soils-Dr. H. E. Hayward and Dr. L. Bernstein, U.S. Salinity Laboratory, Riverside, California.

(vii) Plant physiology-Prof. M. Evanari, Hebrew University, Jerusalem.

(viii) Plant ecology-Prof. G. Lemée, Faculté des Sciences, Paris, and Prof. L. Emberger, Institut de Botanique, Montpellier.

(ix) Human and animal physiology and ecology (including human and animal population problems)Dr. D. H. K. Lee, Quartermaster Research and Engineering Command, Natick. Development of arid lands and its ecological effect on the insect fauna-Dr. B. P. Uvarov, former director, AntiLocust Research Centre, London.

(x) Local energy sources-Mr. E. W. Golding, Electrical Research Association, London, and Dr. Tabor, National Physical Laboratory, Jerusalem.

(xi) Saline water conversion-Dr. E. D. Howe, College of Engineering, University of California, Berkeley.

\section{(2) Appraisal of Unesco's Activities in Promoting Research and Training related to Arid Zones}

This was supplemented by reports on related activities of international governmental organizations 
and by reports from Member States in the major project areas.

Under this heading was presented a comprehensive report by the Secretariat describing Unesco's activities under the major project and the preceding arid zone programme in organizing the symposia and research reviews already referred to, the financial and technical assistance given to a number of research institutes within the arid zone, as in Egypt, Israel, India and Pakistan, the organization of training courses in hydrology, plant ecology, microclimatology, etc., required by the scientific staff of arid lands, and the granting of fellowships in such subjects; the report also underlined the results achieved and the difficulties encountered. The United Nations Water Development Centre, the United Nations Special Agencies, including the Food and Agriculture Organization, the World Health Organization, and the World Meteorological Organization, the intornational scientific organizations, including the International Union of Geodesy and Geophysics, the International Geographical Union, and the International Commission on Irrigation and Drainage, and the Commission for Technical Co-operation in Africa South of the Sahara, also submitted reports of their activities and plans in relation to the arid zone. Finally, most of the Member States of tho region of the major project submitted similar reports.

These various reports demonstrated the close collaboration that exists betwcen Unesco and the Spccial Agencies, and certain international scientific bodies, in the joint attack on the probloms of the arid zones; for example, Uncseo co-operated with the Food and Agriculture Organization on a desert locust ecological survey, on an ecological map of the Mediterranean area, and on forest and grazing policies in arid and semi-arid areas, with the World Meteorological Organization on the measurement of solar radiation and on a climatological survey of solar radiation, with both Organizations on an agroclimatological study in arid and semi-arid areas of the Mediterranean region, with the International Association of Scientific Hydrology in certain hydrological and hydrogeological problems, and with the International Commission of Irrigation and Drainage on the prevention of evaporation losses from irrigation systems.

(3) Studies on Selected Problems illustrating Difficulties in Translating Knowledge into Action in Arid Zone Research, Training and Development

Since it had become increasingly clear with widening experience that a considerable gap tends to develop between the accumulating scientific knowledge of the problems of the arid zono and its application in daily life by the pastoral, agricultural and other inhabitants of the lands concerned, papers were called for devoted essentially to the difficulties of translating knowledge into action in certain typical situations ; accordingly papers were presented under threo main headings as follows :

(i) Nomadism in relation to grazing resources. The Sahara and the Saheli-Prof. R. E. Capot-Rey.

Moving of flocks in the Sahelian zono-O. Bromand and J. Pagot (Prohuza).

The Near East Arab countries-Dr. Mohammed Awad, Cairo.

The mountain and plateau areas of South-West Asia- Dr. F. Barth, Norway.
Nomadic pastoralism-Food and Agriculturo Organization, Rome.

(ii) Alternative uses of limited uater supplies. Studies were presented underlining approaches in four distinctive regions as follows:

United States. Water and the arid zone-Dr. L. Leopold, U.S. Geological Survey, Washington.

Algeria. Possibility of using minor water resources -Mr. G. Drouhin, Director de l'Hydraulique ot de l'Equipement Rural, Algiers.

United Arabic Republic. Egyptian region-Dr. Youssef Simaika, technical adviser, Ministry of Public Works, Cairo.

U.S.S.R. Basic trends and methods of water control-Prof. A. N. Askoschensky, member of Lenin's Academy of Agricultural Sciences, Moscow. Also, Prof. Gilbert White, University of Chicago, considered these regional aspects in a review paper on alternative uses of limited water supplies.

(iii) Public awareness and the educational problem. Undor this heading were submitted papers related to certain special problems in arid zones as follows :

Agriculture (Israel)-Prof. D. Weintraub, Hebrew University, Israel.

Irrigation and land use (Pakistan)-Dr. A. G. Ashgar, Pakistan.

Mineral resources (Sahara)-J. Petit, Prohuza, French Research and Information Centre on Human Problems in Arid Zones.

Agriculture: extension work in the Near EastZ. Behravesh, Food and Agriculture Organization.

\section{(4) Study of the Ferspectives for Future International and National Action in Arid Zone Research, Train- ing and Development}

The discussion at this concluding session of the symposium was based on the previous papers and discussions, and on a paper prepared by Unesco showing the administrative, financial and other considerations to be taken into account in submitting proposals for an extension of Unesco's arid zone research programme.

From this discussion it was clear that the symposium was unanimously of the opinion that the Unesco arid zone research programme should be continued for some years at not less than the present level, and that it should be extended particularly to cover the Latin-American countries; it was considered also that the organization of training courses and fellowships should be expanded. In addition, it was recommended that the Advisory Committee should continue to function on its present lines. Finally, many new projects and lines of research were suggested, including particularly an international study of the artesian basins of northern Africa; the extension of integrated surveys, including surveys relating to geology, geomorphology, water supplies, pedology, plant ecology and microclimate; the study of plant response to environmental factors; soil biology; insect pests and plant diseases; diseases linked with irrigation systems ; and human environmental physiology.

The suggestions and commonts made at the symposium were examined by the Unesco Advisory Committee on Arid Zone Research in a special review session held immediately afterwards, and they will be taken carefully into account when the Unesco governing bodies come to consider the future of arid zone research. The Advisory Committec met also 
during the two days prior to the symposium, and the Sub-Committees on Cartographic Problems in the Arid Zones, and on the Socio-Economic Problems of the Arid Zones, also held meetings at this time.

During the symposium there was an exhibition of maps, photographs and publications illustrating the activities of Unesco, the member States and other bodies; two excellent films were also shown-the Unesco film, "Arid Lands", produced by World Wide Pictures, Ltd., based mainly on scenes and research activities in Pakistan, Israel and Morocco, and a Russian film depicting arid zone development, in respect of irrigation, dry farming and stock raising, in the Karakum and other deserts of the U.S.S.R. Also, a party of delegates visited the phytotron being set up at Gif-sur-Yvette by the Centre National de la Recherche Scientifique; the studies in plant physiology at the phytotron, with special reference to growth under varying conditions of light and temperature, were demonstrated by the director, Prof. P. Chouard.

In respect of the high standard of the papers presented, of the many countries of the arid zone represented, and of the free discussions that followed the papers, the symposium marked an important stage in the study of the arid zones; moreover, it afforded a valuable review of present knowledge and of the scope and nature of future research, and it clearly achieved its objective in presenting, for the consideration of the governing bodies of Unesco, a unanimous and broadly based opinion on the importance of maintaining arid zone research and training at a high level.

Whatever may be the final decision, Unesco's achievements to date will rank high as a contribution to science in making known the problems of the arid zones, and in assisting in their scientific investigation, thereby leading also to the increased economic and social development of these lands.

\section{F. Dixey}

\section{SELF-REGULATION IN LIVING SYSTEMS}

T THE Ottawa symposia on "Self-regulation in Living Systems" organized by Dr. D. K. C. MacDonald of the National Research Council shows signs of becoming an annual series (Nature, 184, $239 ; 1959$, and 183,$370 ; 1959)$. The third meeting was held on March 4, in Montreal, with the Montreal Neurological Institute and McGill University as joint hosts. The attendance exceeded thirty people, representing most medical branches, physies and engineering. The theme was "Tremor", and on this occasion the topics of discussion were introduced by clinicians and illustrated with the willing co-operation of patients. Discussion during the day was general and spirited.

Dr. F. L. MacNaughton (Montreal Neurological Institute) introduced the subject of 'clonus' (alternating contractions and relaxations of muscle). A patient with ankle clonus was introduced and subsequent discussion on the mechanism of oscillation was therefore restricted to this example. The oscillation could be initiated by a sharp application of force to the ball of the foot, and was sustained as long as the force remained. Simultaneous but asynchronous oscillation of both feet could be produced. The oscillation frequency was about 4 c.p.s. and increased only slightly with pressure. The disease had been caused by a spinal tumour pressing on the spinal cord ; the tumour had recently been removed and there was some slight improvement in the patient's condition. She was paralysed from the waist down and could not feel the clonus directly. MacNaughton explained that the disease was known. to be caused at the spinal cord level, rather than higher in the central nervous system. Ankle clonus was produced mechanically by involuntary contractions of the leg's rear lower muscle (gastrocnemius) followed by relaxation under action of the external force. Clonus was not produced by a coupled oseillation between the rear and front leg muscles, and disappeared if the afferent stretch receptors in the gastrocnemius were cut. Any healthy person can produce clonus, for example, by trying to lift an unliftable weight.
After this discussion Dr. MacDonald (National Research Council) exhibited a simple closed-loop system as an illustration of the instability features discussed above. In this demonstration a galvanometer mirror deflected a light beam so as to follow the physical movement of a photo-cell. Normal stable following was produced by negative feedback at some gain. Sufficiently increased gain, however, drove the light spot into a tremor, as did increase of the controllable time-delay in the circuit.

Dr. Burns (McGill) discussed the physiology of the basic causal loop; that is, muscle-stretch receptormultiple afferent nerves - spinal cord-multiple motor neurons-muscle. With nerve propagation speed of order $10^{2} \mathrm{~m}$./sec. and nerve-length of order $\mathrm{I} \mathrm{m}$., the propagation time of the nerve in the loop is 20 msec. (2 nerves); other lag-times in the circuit are negligible. This loop delay-time would produce an oscillation of 25 c.p.s. if it were the direct cause of clonus, but this provides poor correlation with the observed 4-10 c.p.s., and of course this closed-loop action is the same in normal healthy voluntary actions.

The situation is complicated by the fact that the components of a multiple-nerve system do not fire simultaneously, but rather in a statistical pattern approaching a Gaussian distribution of frequency, and propagation velocities are also distributed about a mean in the range $70-120 \mathrm{~m}$. $/ \mathrm{sec}$. Furthermore, the excitability of a nerve follows a time pattern after firing as indicated in Fig. 1.

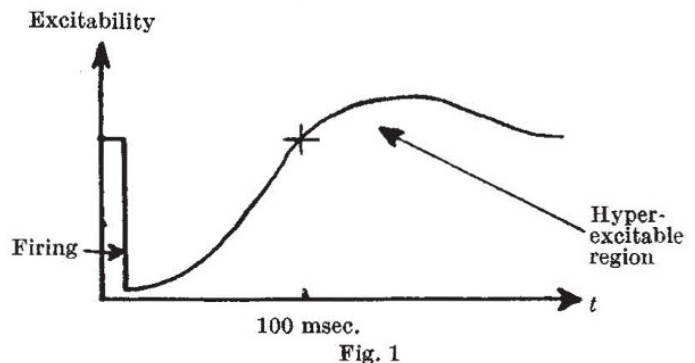

Fig. 1 